\title{
Barkhausen Noise Emission of Surfaces Produced by Hard Milling Process
}

Tomáš Hrabovský, Miroslav Neslušan, Branislav Mičieta, Mária Čilliková, Anna Mičietová Faculty of Mechanical Engineering, University of Žilina, Univerzitná 1, 01026 Žilina, Slovakia. E-mail: tomas.hrabovsky@fstroj.uniza.sk

This paper deals with influence of tool wear on surface integrity after hard turning expressed mainly through the Barkhausen noise responses. Grinding operations can be sometimes replaced by hard machining (hard turning and milling). Chip separation in hard turning differs from mechanism of chip separation during grinding. For this reason surface integrity expressed in variable terms differs. Surface integrity can be expressed in such term as surface roughness, shape deviations as well as characteristics such as residual stresses, structure transformations, and microhardness alteration. Being so, it can be beneficial to apply the suitable nondestructive surface testing techniques to obtain information about surface integrity expressed in complexity of this term. Nowadays, Barkhausen noise technique is widely used in a variety of industrial applications. This technique is sensitive to stress state as well as microstructure features. For this reason, Barkhausen noise emission is used in this study to reveal magnetic and stress anisotropy developed in a certain stage of tool wear. The paper also discusses very high BN responses associated with the specific aspects of produced surfaces.

Keywords: Barkhausen noise, Hard milling, Tool wear

\section{Acknowledgement}

This article was edited under the financial support of VEGA (project No. 1/0223/11 and 1/0097/12) and KEGA (project No. 023TUKE-4/2012) agencies.

\section{References}

[1] BARKHAUSEN, H.: Phys. Zeitschrift 20 (1919) 201.

[2] ABUKU, S., CUllity, R. D.: A Magnetic Method for the Determination of residual Stress, Exp. Mech. 11. 1971.

[3] KARPUCHEEWSKI, B.: Introduction to micro magnetic techniques, ICBM1 report Hanover. 2002.

[4] MALKIN, S., GUO, C.: Thermal Analysis of Grinding, CIRP 56, p. 760 - 782. 2007.

[5] MOORTHY, V. et all.: Evaluation of heat treatment and deformation induced changes in material properties in gear steels using magnetic Barkhausen noise analysis, ICBN 03, Tampere, Finland. 2001.

[6] NESLUŠAN, M., ROSIPAL, M., OCHODEK, V.: Analysis of some aspects of surface integrity after grinding and hard turning trough Barkhausen noise, ICBN 09, Hejnice, Czech Republic. 2011.

[7] ROSIPAL, M.: Využitie Barkhausenovho šumu na štúdium integrity obrobených povrchov, Diplomová práca, Žilina. 2012.

[8] TONSHOFF, H. K., ARENDT, C., BEN AMOR, R.: Cutting of hardened steel. CIRP Annals 2/2000, pp. 547 567.

[9] TÖNSHOFF, H. K.: Environmental and Ecological Aspects of Cutting - State. Developments, Potential, I.C.E.M. Meeting, Ecology and Economy in Metal Forming and Cutting, Netherlands, 1997.

[10] BRANDT, D.: Randzonenbeeinflussung beim Hartdrehen. Dr.-Ing. Dissertation, Universität, Hannover, 1995.

[11] KARPUSCHEWSKI, B., SCHMIDT, K., PRILUKOVA, J., BEŇO, J., MAŇKOVÁ, I., HIEU, N. T.: Influence of tool edge preparation on performance of ceramic tool inserts when hard turning, Journal of Materials Processing Technology, volume 213, November 2013, p. 1978-1988.

[12] JERSÁK, J., et. al.: The Integrity of the Surface after Milling of Quenched Bearing Steel. Manufacturing Technology, No. 4, pp. 13 - 20. ISSN 1211-4162. 2009.

[13] RUZICKA, L., MADL, J.: The importance of measured values number in evaluating the wear size of inserts, Manufacturing Technology, December 2012, Vol. 12, No. 13, ISSN 1213-2489.

[14] WANG, J.Y. , LIU, C. R.: The effect of Tool Flank Wear on the Heat Transfer. Thermal Damage and Cutting Mechanics in Finishing Hard Turning. CIRP Annals 48/1/1999, pp. 53 - 56. 
[15] NESLUSAN, M., BLAŽEK, D., HRABOVSKÝ, D. , BUKOVINA, M.: Magnetic anisotropy in hard turned surfaces, Acta Physica Polonica A, 03/2014 (manuscript in print).

[16] OCHODEK, V., NESLUŠAN, M., ROSÍPAL, M., ŠÍPEK, M.: Non-destructive analysis of surface integrity in turning and grinding operations, Manufacturing Technology, December 2010, Volume 10, ISSN 1213-2489.

\section{Paper number: M201404}

Copyright @ 2014 . Published by Manufacturing Technology. All rights reserved. 